\title{
11 Evidence for Arsakid Economic History
}

\section{Introduction}

\section{I.1 Methodological Problems I: Tradition, Research, and Popular Views}

For anyone who is concerned with the history, culture, and economy of the ancient Iranian empires there is a serious problem: The views of the inhabitants of their heartlands, that is, above all the Iranian highlands, have passed down to us in Late Antique or Early Islamic versions only. Exceptions are royal announcements, inscriptions, coins, images, and administrative documents. The reason for the lack of nonofficial source material is the decidedly oral character of the Iranian tradition. ${ }^{1}$ Texts related to religious ritual, like the Avesta, may have preserved large parts of original ideas and the original shape of its oral presentation. The more secular parts of the tradition, however, were subjected to fundamental change and adaptation. The complete disappearance of the Achaemenid kings from the socalled Iranian National History, which probably happened in Parthian times, can hardly be explained otherwise. The Arsakids were also denied their fair share of the historical tradition by the last Sasanian kings. We can actually speak of Iranian literature only since the late Sasanian period, when a wealth of historical, religious, geographical, didactic, and entertaining literature emerged in Iran - probably initiated not least by the rivalling secular and religious book cultures of the West. ${ }^{2}$

This means that the history of pre-Islamic Iran must be reconstructed to a considerable extent from foreign and later, that is, broken and partly hostile or biased, traditions: the Greek, Babylonian, Elamite, Egyptian, and Aramaic ones during the Achaemenid period; the Graeco-Latin, Babylonian, Aramaic, Middle Persian-Sasanid, and Chinese ones under the Arsakids; and the Graeco-Latin, Armenian, Syriac, and Arabic ones in Sasanid times. In the context of the history of events as much as in the history of structures, this requires a high degree of source-critical vigilance and some effort not to succumb to the horror vacui by forming airy hypotheses. It must always be remembered, moreover, that in the Achaemenid and Arsakid periods Iran, rather than Mesopotamia, which is much better represented in written sources, formed the heart of the empire. However, dealing with non-Iranian traditions opens up ways to a better understanding of alien perceptions of Iranian institutions as well as to uncovering the reasons for the emergence of stereotypical ideas and topical distortions in this very foreign tradition. Besides, in the last decades,

\footnotetext{
1 Huyse 2008.

2 For the literature of pre-Islamic Iran, see Emmerick and Macuch 2009.

Ә Open Access. (c) 2020 Josef Wiesehöfer, published by De Gruyter. (cc)BY-NC-ND This work is licensed under the Creative Commons Attribution-NonCommercial-NoDerivatives 4.0 License.

https://doi.org/10.1515/9783110607741-017
} 
apart from an abundance of individual studies, excellent editions of the respective sources have been published. ${ }^{3}$

Quite apart from the inadequacies of the sources, research on the history of preIslamic Iran continues to suffer from several problems, both in academic and popular historiography. First, the tradition of essentialist-holistic and stereotypical notions of the ancient Near East contrasted with images of the Graeco-Roman world, Europe, and the Occident (Abendland) that are just as topical though quite different and more positive or 'progressive'4 is still unresolved. Second, there is clearly a political abuse of ancient Iranian history and its traditions in the form of historical myths both in Iran and in the West (see below). Third, there is an unfortunate disciplinary separation in research and academic teaching between Near Eastern studies and ancient history where Iran - not only for practical linguistic reasons - comes into view only at times when Iran and the Mediterranean powers entered into war with each other, or when the Graeco-Macedonians or Romans ruled over the Near East. It is only in recent decades that transcultural approaches in history and forms of inter- or even transdisciplinary cooperation have managed to cross these borders. ${ }^{5}$ Last but not least there is the infertile debate about the value of certain traditions - Greek and Roman versus 'Oriental' sources - which often enough makes us forget that not only historical realities, but also forms and images of peoples' dealings with the unfamiliar and the foreign are historically relevant and worth investigating.

Moreover, the history of the relations between the Iranian empires and the Greek poleis, the Macedonian kingdoms, or the Roman and East Roman Empires is still written mostly from the Western point of view, that is, as part of the history of Greece and Rome. It continues to be presented - not least for reasons of European self-assurance - as a history of constant confrontations between the states of the West and the East, or as an encounter between a foreign and a Western, or anachronistically called 'European,' world allegedly close to us Europeans. Often enough, this is based on ancient models that also constructed Eastern 'others' as a kind of counterworld. ${ }^{6}$ A reference to the pair of opposites of 'Greek (that is: European) freedom' versus 'Oriental despotism,' or to the Battle of Salamis at the presumed

3 Achaemenid royal inscriptions: Schmitt 2000; 2009; Sasanian royal inscriptions: Back 1978; Huyse 1999. Other sources: Achaemenids: Kuhrt 2007; Parthians: Hackl, Jacobs, and Weber 2010 (cf. the review Hartmann 2011); Sasanians: Dodgeon and Lieu 1991; Greatrex and Lieu 2002; Dignas and Winter 2007.

4 Wiesehöfer 2006; 2007; 2017a.

5 See, e.g., the Achaemenid History Workshops published in Sancisi-Weerdenburg et al. 1987-2010; Wiesehöfer 1998; Curtis and Stewart 2005; 2007; 2008; Wiesehöfer and Huyse 2006; Gyselen 2009; 2010 (Sasanians); Curtis and Simpson 2010; Jacobs and Rollinger 2010; Henkelman and Redard 2017 (Achaemenids); Jacobs, Henkelman, and Stolper 2017; Wiesehöfer and Müller 2017 (Parthians). 6 See von Reden and Speidel, ch. 17, this volume. 
end of the Graeco-Persian Wars as the 'birth cry of Europe' may suffice to illustrate this rather fundamental bias in European historiographical traditions. ${ }^{7}$

A scheme of succession of world empires, furthermore, was laid down in Greece by the authors Herodotus and Ktesias, ${ }^{8}$ later living on in the European idea of a translatio imperii, and in its salvific-historical manifestations dating back to the book of Daniel as an idea for structuring history. ${ }^{9}$ To this day, with clear chiliasticapocalyptic references, it is still virulent in Western fundamentalist circles. Together with Hegel's idea of a teleological world history, this sequential history has attributed the role of a childhood stage of world history to the ancient Near Eastern cultures and empires, including the Iranian ones, and torn apart the links of the European cultures with the East and the later Islamic Near East. The role of the ancient Iranian empires in these narratives, however, is not limited to that of being the great adversary or partner of the Greeks and Romans. Iranian history also became relevant, among other things, by the fact that the political unification of the Near East under the Greek and Roman aegis permitted cultural, religious, ideological, and economic developments that radiated both to the West and to the East, and into the imperial territories themselves. ${ }^{10}$

Finally, it is not only in Europe that a fair appreciation of the historical role of the Iranian empires is lacking until today. Even in today's nation state of Iran, which is only a part of Ancient Iran, its evaluation is biased. On the one hand, the Teispids/Achaemenids, and Kyros as the alleged founder of the idea of human rights, were reimported to Iran from the Western tradition only under the Pahlavis, and are considered by the Iranian elites both in and outside Iran as historical benefactors. ${ }^{11}$ On the other hand, the Sasanians, strongly anchored in the Iranian tradition, are understood in the same circles - on the basis of the Iranian mythical tradition as great adversaries of the Turanians in the East (often enough equated with the Turks), the inhabitants of Rum in the West (Greeks and Romans or Europeans), and sometimes also of the Arabs in the South. ${ }^{12}$ And thus, it is not surprising that still today Alexander's campaigns and the appearance of the Arab Muslims - like the so-called Mongolian invasion - appear to some Iranians as world-historical caesuras which endangered the survival of 'Iranianness' to the extreme. Only thanks to the extraordinary tradition and talent of the Iranian inhabitants those catastrophes

\footnotetext{
7 Nippel 2013. For the concept of oriental despotism and the related neo-Marxian concept of the Asiatic mode of production, see Manning 2010, 36-45; and, in this volume, Dwivedi, ch. 15; Fabian, ch. 13; Morris, ch. 16.

8 See von Reden, ch. 10.B, this volume.

9 Kosmin 2019, esp. 139-162.

10 On these trends, see Wiesehöfer 2005; 2006. A dissertation by M. Oellig (Kiel) on the genesis of the scheme of the sequence of world empires has just been completed.

11 Wiesehöfer 1999.

12 Wiesehöfer 2005.
} 
did not impair the unchangeable core of 'Iranianness.' The Parthians, by the way, are almost unknown in both East and West.

\section{I.2 Methodological Problems II: The Arsakid Empire in Time and Space}

The Arsakids were not just, as Pompeius Trogus in Augustan times has it, heirs of the Macedonian Empire alongside the Romans. Nor were they, as represented in Roman art, barbaric enemies and fascinating inhabitants of an orbis alter, inferior and yet ultimately indomitable, as Trajan, Septimius Severus, and Caracalla had to experience painfully. ${ }^{13}$ Political and economic contacts and agreements were therefore advisable and profitable for both sides, as for example with regard to the Armenian question in the time of Nero, and for trade in the time of Hadrian and Antoninus Pius. Eurasia presented itself in the time of the Seleukids and Parthians as a "world of cultural entanglement, wherein cultural processes ... [took] place on an intra-cultural level (within the same cultural sphere) rather than on an inter-cultural one (between different monolithic cultures), and in which emplaced localities ... [were] formed through intra-cultural appropriation and recontextualization of translocal elements," as a new work on "Eurasian localisms" has rightly emphasized. ${ }^{14}$ Regionally shared goods, techniques, and cultural practices were exchanged and recontextualized on the local level "for social purposes, which may or may not have been imbued with ethnic significance." 15

Usually, the beginnings of intensive and allegedly continuous East-West connections, which, since the nineteenth century, have been summarized under the problematic term of 'Silk Roads,' are transferred to the period of interest here. However, the notion of Silk Roads by land and sea as clearly identifiable continuous trade routes between China on the one hand and the Roman Empire, Byzantium, or Europe on the other is historically unsupportable. ${ }^{16}$ The testimonies from China show a particular Eastern interest in certain parts of Central Asia, not least the Ferghana valley, in possible allies in this very area and the border regions of Iran, also in economic and cultural ties with the people living there. But they only rarely mention Rome and even more rarely show an interest in getting in touch with what Western scholars normally call 'the West.' ${ }^{17}$ On the other hand, we can certainly see on the Roman side an interest in economic contacts with China, but - apart from a problematic case from Marcus Aurelius's reign - we know nothing about the fact

13 See Weaverdyck, ch. 7, this volume.

14 Hoo forthcoming.

15 Hoo 2018, 179.

16 Rezakhani 2010; see also von Reden and Speidel, ch. 17, this volume.

17 Leese-Messing, chs. 5 and 12.A, this volume. 
that such a situation really came about. The concept commonly found in research literature of the inhabitants of Syria, Mesopotamia, Iran, and Central Asia being pure intermediators for goods moving between the Roman Empire and China "is an anachronistic and largely Eurocentric view of world history." 18 By degrading Palmyrenians, Charakeneans, Parthians, and Sogdians to pure middlemen whose task was to ensure the flow of goods between Han China and the Roman Empire, i.e., the two greatest empires of antiquity, historical Silk Road studies have deprived themselves of their greatest potential. The world east of the Euphrates was merged economically into the western part of the Silk Road, while Central Asia became an essentialized concept, organized either around the problem of the relationship between 'nomads' and sedentary peoples, or as the connecting link between the world empires of Rome and China. ${ }^{19}$

\section{I.3 General Research Trends in Arsakid History}

The military conflicts between Rome and the Arsakid Empire used to be the main focus of historical attention, but a change of perspective has taken place since the 1990 s. $^{20}$ Without neglecting the previous research focus, problems of the local tradition, studied on the basis of written as well as numismatic and archaeological sources and material (see below), the structure of the Arsakid Empire, including the relationship between the center and particular local powers, regional studies, ${ }^{21}$ and the literary image of the Parthians ${ }^{22}$ shifted to the foreground. Another new focus has been on the Parthian connections to, and interactions with Central Asia, China, and other eastern polities, including the Parthian role as either producers or mediators of goods and ideas. ${ }^{23}$ The Arsakids' dealings with their Greek and Babylonian subjects $^{24}$ and the Arsakid share in the promotion of Greek paideia ${ }^{25}$ have also attracted much interest.

As far as the end of Arsakid rule in the 220s CE is concerned, no longer the structural instability of the ruling power but a bundle of highly contemporary factors are taken into consideration. Among these were the reemerging disputes be-

18 Rezakhani 2010, 433.

19 See also Morris, ch. 16, this volume.

20 Most important general literature on the history of the Arsakid Empire: Schippmann 1980, Wiesehöfer 2004a, 115-149; 2014; 2015a, 92-96; Huyse 2005; Brosius 2006, 79-138; Hackl, Jacobs, and Weber 2010; Shayegan 2011; Hauser 2012; 2013; Jacobs 2014; bibliography: www.parthia.com. A textbook on the Parthians, edited by R. Shayegan, is in preparation.

21 Hackl, Jacobs, and Weber 2010; Schuol 2000; Marciak 2014; 2017; Luther 2015; Potts 2016.

22 Hauser 2005; Lerouge 2007; Wiesehöfer and Müller 2017.

23 Wiesehöfer 2004b; 2016.

24 Dąbrowa 2011 (cf. the review Kettenhofen 2012); Grajetzki 2011; Wiesehöfer 2015b; Olbrycht 2017.

25 Wiesehöfer 2000; Olbrycht 2014; Hoo forthcoming. 
tween Rome and the Arsakid Empire at the beginning of the third century, the throne dispute between Artabanos IV and Vologases VI, and the increasing ambitions of the early Sasanians in Fars. And even though we have only a few meaningful testimonies for the period of transformation, it cannot be doubted that the Sasanians, despite setting some new accents, imitated the Arsakids in many respects, taking over many politically established Arsakid institutions and functionaries in order to give their new rule the necessary stability.

\section{Sources on the Economic Conditions in the Arsakid Empire}

If one tries to weigh the evidence of the Arsakid period according to its local, temporal, and content-related proximity to the object of investigation, priority should be given to the following documents: 1 ) inscribed ostraca (sherds) from the old Arsakid centers Nisa in today's Turkmenistan and Shahr-i Qumis (Hekatompylos?) in Iran; 2) on parchment from Avroman in Western Iran; 3) on parchment and papyrus from Dura Europos in Syria; 4) in cuneiform script on clay tablets from Babylonia; as well as 5) to the work Stathmoi Parthikoi of the Arsakid subject Isidoros of Charax; 6) to the results of archaeological surveys, especially from the Susiane or from Eastern Iran; 7) to the Arsakid coins; this group of sources is then followed by the foreign tradition; not least 8) the particularly significant inscriptions from Palmyra as well as information provided 9) by Chinese historiography and 10) Greek, Latin, as well as Christian and Jewish literature. ${ }^{26}$ In the remaining part of this brief survey, I shall look at each of these categories of evidence in turn.

\section{II.1 Ostraca from Nisa and Shahr-i Qumis}

In Nisa, the original Arsakid residence in Turkmenistan (near present-day Ashgabat), Soviet excavators found more than 2,000 ostraca from nine wine cellars ( $m a$ dustan) with 2,758 texts from a 'record office.' These texts dating mostly to the 70s and 60s BCE mainly provide details about deliveries of wine to the palace from the vineyards of various estates, temples or private people, or give information on the allocation of food to those employed there. Many of them mention Arsakid officials with their names and titles, from a wine supplier up to the satrap. The ostraca are probably to be interpreted as provisional notes for the identification of the contents of the vessels, which were to be followed up by a summary on some other writing

26 For a general overview of the sources, see Wiesehöfer 1998; and of the economically relevant testimonies, see Hackl 2010. 


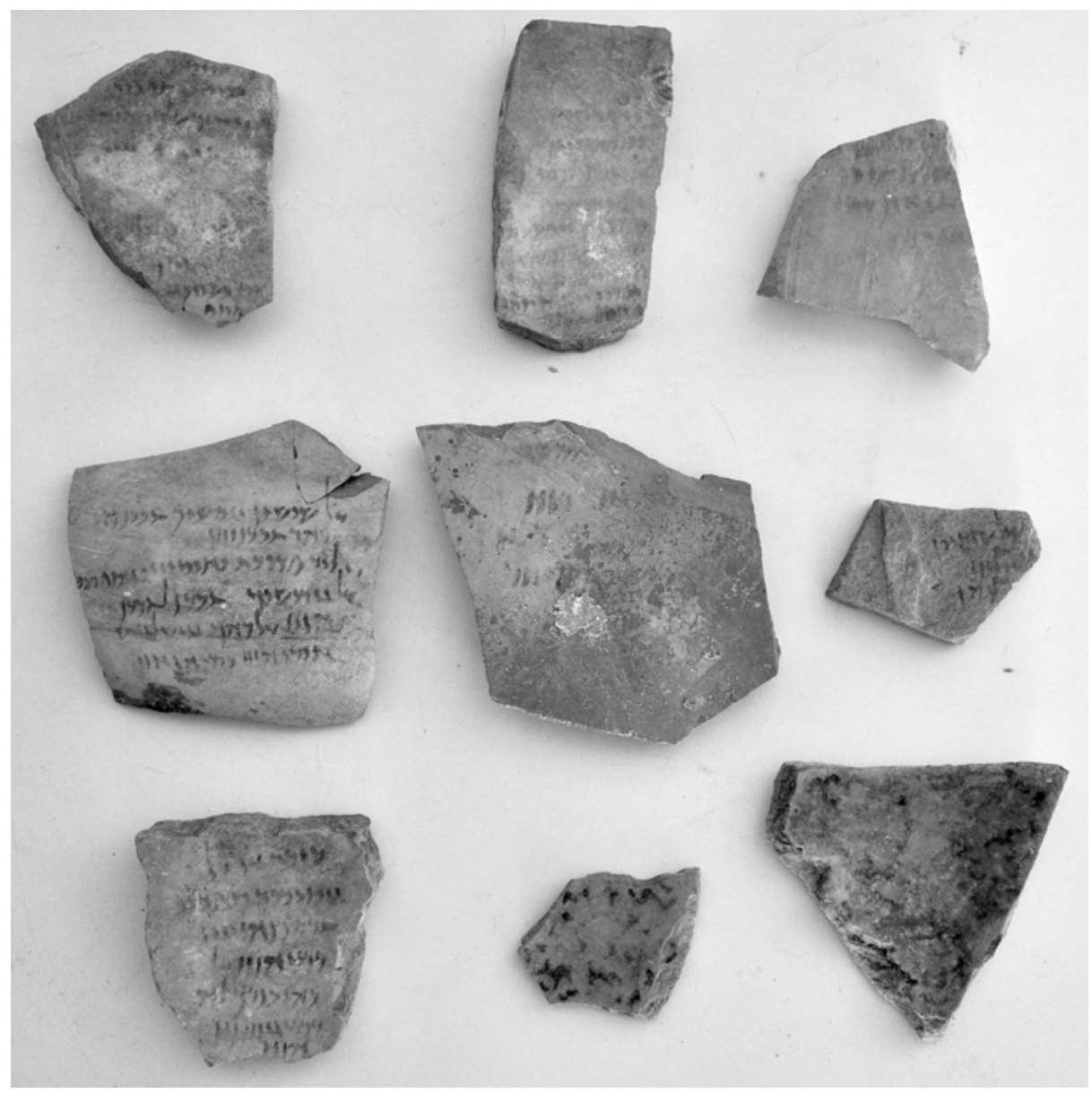

Fig. 1: Ostraca from a storehouse in the SW corner of Nisa (excavated between 2008 and 2015). (c) Archive of Centro Scavi Torino - CRAST.

material, perhaps leather. In addition to palaeographical, historical linguistic, and onomastic information ${ }^{27}$ they offer evidence on viticulture, wine varieties, wineries, administration and taxation, and the relevant terminology. In addition, the Nisa ostraca provide particulars on the calendar, on questions of chronology, religion, and the genealogy of individual kings. ${ }^{28}$ It seems, moreover, that a number of estates and vineyards were not only named after living and deceased Arsakid kings,

27 For personal names in Arsakid epigraphical sources, see Schmitt 2016.

28 Editions: Diakonoff and Livshits 1976-2001; Morano 1996; Livshits and Pilipko 2004; Livshits 2006; Morano 2008; 2013; Weber 2010b (selection with German translation); commentaries: Schmitt 1998, 168-170; Weber 2010b. 
but that the goods delivered from the estates "supported some sort of cult for the memory and the benefit of the king's soul." 29

\section{II.2 Documents from Avroman}

In 1909, a farmer found a vessel in a cave of the Kuh-i Salan Mountains near Shari Owraman (Hawraman, Avroman) in the Iranian part of Kurdistan. The vessel contained several ancient texts from Parthian times written on parchment now kept in the British Museum. The three texts are private documents and contain purchase or lease contracts for parts of a vineyard. The first two documents are available as double documents in two versions of the text, however, with partly significant deviations. The extant parts are written in Greek language on the back of document 1,

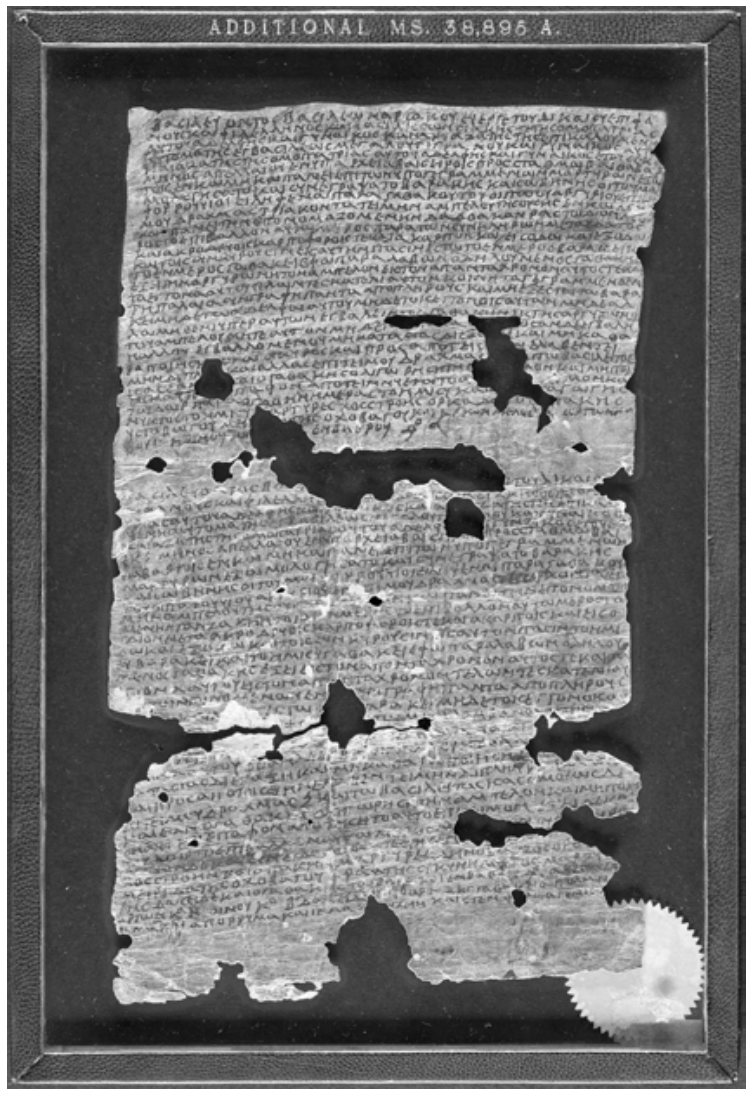

Fig. 2: Avroman Document I (Additional Manuscript 38895a f001r). () British Library.

29 Canepa 2018, 237-238. 
yet there are five Parthian text lines that unfortunately are hardly legible. The third document is written in Parthian language. Documents 1 and 2 refer to the vineyard Dadbakan in a place called Kophanis (Kopanis). Document 3 relates to the "half vineyard Asmak, which is near the farmland" and which is sold by Pataspak, the son of Tiren from Bod, to Avil, the son of Bashnin, and his brother, for 65 drachms. The documents are important sources for the legal and documentary system in the Arsakid Empire, the position of Greek as an administrative language and a lingua franca there as well as for the history of the Parthian script and language and for Parthian onomastics. ${ }^{30}$ On the basis of the references these documents give to the kings and their wives, it has recently been shown that the three documents belong to the Arsakid era. Document 1 can now be dated quite precisely to the month of November 24 BCE, document 2 to the year $43 / 4 \mathrm{CE}$, and document 3 to approximately December 52 CE. ${ }^{31}$

\section{II.3 Documents from Dura Europos}

The parchments and papyri from Dura Europos, which was under Arsakid control between 116 BCE and 164/5 CE, contain some important detail for the economic and administrative history of the Arsakid Empire. Especially interesting for the present purpose are the two parchments, PDura 18 and 19, in which a tax collector (praktor), settled in an urban context, is mentioned, as well as PDura 20, in which the "strategos of Mesopotamia and Parapotamia" and "Arabarch" Manesos also functions as tax collector (paraleptos) and is supported by his subordinate, the eunuch Phraates, the "chief of the tax system" (arkapates). ${ }^{32}$ Two less significant ostraca with name lists in the Parthian script from Shahr-i Qumis and others from Tureng Tepe, Nippur, Qosha-depe (booking entries on flour), Kunja-kala, and the Merv oasis conclude this group of records. ${ }^{33}$

\section{II.4 Tablets from Babylonia}

The late cuneiform written tradition from Babylon contains texts with religious, astronomical-astrological, historiographical, economic, and administrative content.

\footnotetext{
30 Editions: Documents 1-2: Minns 1915; Rougemont 2012, no. 73-74; Document 3: Haruta 2001, 125, 128; Livshits 2010, 164-165; Documents 1-2 (with German translation): Thommen 2010a; Document 3: Weber 2010a; commentaries: Weber 2010a; Thommen 2010a; Luther 2018.

31 Luther 2018.

32 Editions: Welles, Fink, and Gilliam 1959; Cotton, Cockle, and Millar 1995; Thommen 2010b (PDura 18 and 20 with German translation); commentaries: Millar 1998a; Hackl 2010, 123; Thommen 2010b.

33 Schmitt 1998, 170-171; Schmitt 2016, passim (with further literature published in the meantime).
} 
Yet it must be considered that cuneiform came out of use as a writing system in Arsakid times, that the extant material is incomplete, and that we therefore run the risk of concluding from the absence of texts that institutions or traditions were also absent or deliberately abandoned. Among the 'economic texts,' mainly originating from Uruk and Babylon and dating to Arsakid times, are the so-called Astronomical Diaries with dated quantitative observations from the Neo-Babylonian period up to the first century CE. In addition to observations of the moon, the planets Mercury, Venus, Mars, Jupiter, and Saturn, comets, the weather and the water level of the Euphrates, special local events, and the price in silver of a fixed number of foodstuffs and export products are also mentioned, among them fish, barley, mustard, cress, sesame, and wool. ${ }^{34}$ The cuneiform texts also include the tablets of the socalled Rahimesu Archive, all of which date back to just two years, 94-93 CE or 154155 Arsakid Era and 218-219 Seleukid Era. It has been noted that

in fact, all texts belonging to his archive are terse and stereotyped lists of income and expenditures which consist of an introductory statement giving the amount of the income collected in a certain sanctuary for a specific period of time. This introduction is followed by a varying number of specific expenditures ... and the remainder of the silver (i.e., the balance) that was deposited with Rahimesu ... The transactions recorded in these lists were exclusively conducted in silver and thus mark the last phase of the general trend of an increasing monetization of economic exchange that can be observed in the course of the first millennium $\mathrm{BC}$... [T] he right to the collection of temple income was farmed out to private businessmen against the obligation of paying out salaries for temple personnel and meeting other expenses of the temples such as the acquisition of supplies for the upkeep of the offering system. ${ }^{35}$

Information on money, prices, wages, and agricultural production (wheat, rye, dates) is not the least of the factors that make these archival texts invaluable sources for economic questions.

\section{II.5 The Stathmoi Parthikoi}

The Stathmoi Parthikoi of Isidoros (early first century CE) from the city of Spasinou Charax (the capital of Charakene), lists in its first part 31 places on the route between Zeugma-Euphrates and Seleukeia-Tigris (see ch. 6, map 1). ${ }^{36}$ It gives accurate distances between them up to a total of 171 schoinoi. ${ }^{37}$ In the second part it describes

34 Editions: Hunger 1988-1996; 2001; 2006; 2014; Böck 2010 (selected documents with German translation); commentaries: van der Spek 1997-1998; Böck 2010.

35 Hackl 2016, 87-88; editions, translations, and commentary of the published texts in van der Spek 1998 with new additions in Hackl 2016.

36 For editions, see Hartmann 2017, 87 n. 1; for the most important recent literature, Hartmann 2017; Hauser 2017; Schmitt 2017; Schuol 2017; Hartmann 2018, 446-450 (in each case with further literature); Morris, ch. 9, this volume.

37 The schoinos was of variable length, but on average, a length of $10.5 \mathrm{~km}$ can be used (Der Neue Pauly, s. v. schoinos). 
the regions further east up to Alexandria-Arachosia. However, the number of places is much smaller, they are almost exclusively larger cities with hardly any distance data given between them apart from the total distance of 700 schoinoi. For a long time, scholars assumed some practical purpose of the work as either the description of an overland trade route, a semiofficial Parthian itinerary, or the result of military exploration and preparation for Roman campaigning. However, there is much to suggest that we are dealing with a nonuniform compilation of texts, which in the first part described the course of the central east-west route from Zeugma to Seleukeia, oriented toward the Seleukid city foundations, and in the second part offered an "abstract geographical description of the regions between eastern Assyria and the Kushan Empire." 38 It rather bears witness to the spread of geographical knowledge in Arsakid Mesopotamia and Babylonia in the first century CE. ${ }^{39}$

\section{II.6 Archaeological Surveys}

Among the archaeological surveys of particular economic and historical significance, those from Susa and the surrounding Susiane are particularly noteworthy. As far as the city is concerned, its growing prosperity in Arsakid times is shown by a remarkable increase in land reclamation, and significant improvements in the irrigation network. ${ }^{40}$ The excavations at Nisa and in other parts of Northeastern Iran are also becoming increasingly important in economic terms. ${ }^{41}$

\section{II.7 Coins}

Arsakid coins are among the most important primary sources for the history of the Arsakid Empire. They have been studied intensely for the valuable information they hold about the succession of Arsakid rulers and about Arsakid mints. In addition, their images and legends contain important information about ruler ideology and representation, traditional costumes and armament, religious conditions, language policy, and much more. ${ }^{42}$ Yet they have also a great and largely unexplored poten-

38 Hauser 2017, 165.

39 Hauser 2017, 165.

40 Wenke 1975-1976, 115-131.

41 Cf., e.g., Lippolis and Manassero 2015.

42 Overview: Sinisi 2012; coins and 'Parthian Art': Sinisi 2014. In the project Sylloge Nummorum Parthicorum (SNP), in which a volume has already been published, the collections of Arsakid coins in the Münzkabinett of the Staatliche Museen zu Berlin, in the Department of Coins and Medals of the British Museum (London), in the American Numismatic Society (New York), in the Cabinet des Médailles of the Bibliothèque nationale de France (Paris), in the National Museum of Iran (Tehran) and in the Münzkabinett of the Kunsthistorisches Museum (Vienna), and supplementary material from coin trade publications shall be published. In addition, the system and chronology of the Arsakid coinage - separated by mints - will be examined in detail for the first time. 
a)
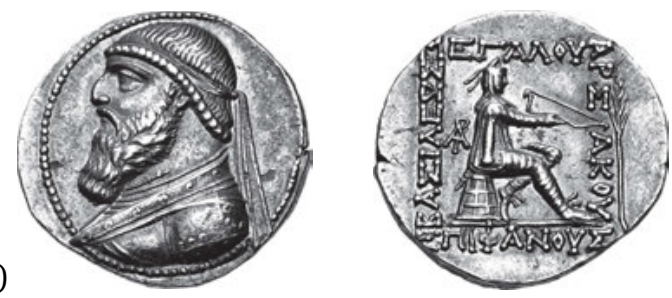

b)
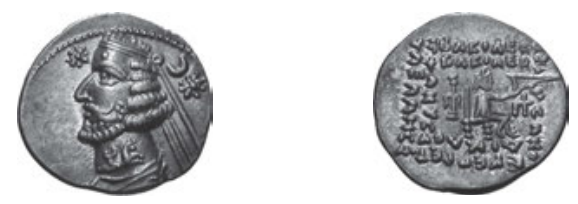

c)
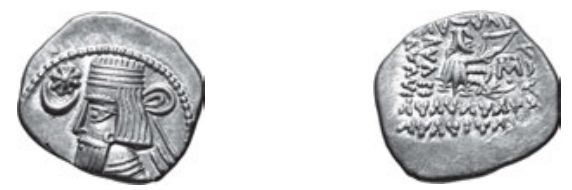

Fig. 3: Arsakid Coins: a) Tetradrachm of Mithradates II with a monogram on the reverse (a magistrate's monogram?) (Classical Numismatic Group 106 (13-9-2017), lot 533, 30 mm., 15.89 g., $12 \mathrm{~h}$, Sellwood 24.5 corr). (C) Classical Numismatic Group; b) Drachm of Orodes II from Rhagae with the relevant mintmark (Agora Auctions, Numismatic Auction 40 (8-9-2015), lot 53, 19.8 mm., 4.10 g., 1h, Sellwood 48.10). () Agora Auctions; c) Drachm of Artabanus II from Mithradatkart with the relevant mintmark (Classical Numismatic Group E-auction 400 (28-6-17), lot 455, 19 mm., 3.85 g., 12h). @ Classical Numismatic Group.

tial for the analysis of monetary and economic conditions in Iran and its neighboring countries, such as coin circulation, coin deterioration, and conditions of hoarding.

\section{II.8 Palmyrene Caravan Inscriptions}

Among the foreign sources, two corpora are of particular importance, especially for questions of trade by land and by sea. One is the so-called corpus of the Palmyrene caravan inscriptions, the other the historiography of the Han dynasty, discussed in the following section. The corpus of the Palymyrene caravan inscription is a group of 34 honorary inscriptions for people who have rendered outstanding services to the safe arrival of the caravans in Palmyra. The inscriptions are often bilingual in both Palmyrenian and Greek. ${ }^{43}$ Among other things, they provide information on

43 Fox and Lieu 2005; for discussions, Young 2001, 236-275; Millar 1998b. 
the scope of Palmyrene economic activity beyond the borders of the Roman Empire, Palmyrene presence in Seleukeia-Tigris, at Babylon, Vologesias (where even a temple for the Augusti is attested), ${ }^{44}$ as well as Forat and Spasinou Charax. They provide vivid evidence for transimperial exchange in the Gulf area, with the Arsakids, their Charakenean and other vassals in Mesopotamia as well as the Palmyreneans as important agents in that trade. At the same time this group of evidence calls for clarifying more precisely the relations between the great imperial powers, these great powers and their own and foreign subjects, and the historical circumstances under which these contacts were established and maintained, and the question of a possible active Arsakid policy of trade. ${ }^{45}$

\section{II.9 Chinese Historiography}

There were three phases of Han Chinese contacts with the Arsakid Empire (Anxi): the diplomatic journeys of Zhang Qian and the ensuing presence of China in Dayuan (Ferghana) (ca. 126-91 BCE), the Protectorate of the Western Regions (59 BCE-9 CE), and the periods of intensive military presence in the Tarim Basin under Dou Gu (73-77 CE), and Ban Chao and his son Ban Yong (91-123 CE). ${ }^{46}$ Chinese sources such as Sima Qian's Shiji, Ban Biao's Hanshu, and Fan Ye's Hou Hanshu provide information on urban development, rice and wheat cultivation, wine production, as well as trade and coinage of the Arsakid Empire. ${ }^{47}$

\section{II.10 Graeco-Roman Texts}

The Periplus Maris Erythraei (PME) is the most important testimony on Arsakid trade from the perspective of the Roman Empire. ${ }^{48}$ Beyond its character as some technical manual on navigation and trade in the Red Sea, it testifies to the penetration of literary concepts into the world of merchants, as well as to that of perceptual patterns of the latter into literary circles. ${ }^{49}$ Of interest to us here are the descriptions of the shipping route from the Indian port of Barygaza (Bharuch) via Omana to Spasinou Charax and Apologos at the Shatt al-Arab and to Kane in Arabia, respectively, and the hint that from ports of the Arsakid Empire "pearls in large quan-

44 Speidel 2016, 110-114.

45 Important inroads into these questions have been made by Gregoratti 2010 and Hartmann 2018.

46 See Leese-Messing, ch. 4; Morris, ch. 9, this volume.

47 Leslie and Gardiner 1996, passim; Posch 1998. Texts relating to Parthia are collected by Golze and Storm 2010.

48 See von Reden, ch. 10.B, this volume.

49 Edition: Casson 1989; Thommen 2010c (selections [ch. 35f., 38] with German translation); for the character of the work, Ruffing 2017 (with the older literature). 
tities ..., local garments, wine, dates in large quantities, gold and slaves” had been transported both to Barygaza and to Arabia, in addition "from Omana to Arabia local boats tied together, which are called madarate." 50 However, whether or not the "large ships" sent out from Barygaza, loaded with "copper, teak, beams, seedlings, sandalwood, and ebony trunks," or the incense shipments from Kane to Omana were unloaded in ports under Arsakid control, cannot be said.

Several authors living and writing under the Roman Empire, in particular Pompeius Trogus (preserved in Justin), Strabo, Pliny the Elder, Josephus, Tacitus, Arrian, and Herodianos expressed their views on the Parthians. Yet only rarely do they provide reliable information on the economic conditions in the Arsakid Empire, such as observations on agricultural production, import and export products, or artisan production sites. ${ }^{51}$ However, the importance of the latter can be gleaned from the mere mention of pearl fishing, mining, special armament, traditional costumes, and local writing materials (parchment) that suggest extensive local manufacture. Late Christian and Jewish texts give indications of traders and merchants, including Jews, who transported 'goods of silk.' The Song of the Pearl from the Acts of Thomas also mentions valuable Parthian import and export products. ${ }^{52}$

\section{Conclusion}

If one systematizes the economically relevant information that our sources provide, then the following picture emerges. First, the hazards of transmission and loss of material determine the state of the extant source material, which can only offer glimpses into a few aspects of complex economic contexts. The priority of the spoken over the written word in the core territories of the empire, unprocessed or fragmented fields of research, and ideologically biased views from outside make the situation even more difficult.

Second, the Arsakid Empire is still, like in our foreign sources, primarily seen along ethnic or Orientalist lines and as the great adversary of Rome. Like the territorial states of Central Asia or the Arsakid 'vassal kingdoms,' the Arsakid Empire is fixed on its role as a mediator of ideas and goods between East and West, between the great empires of China and Rome, which are often compared. The same applies to the Arsakid Empire's role as predecessor of the much better attested Sasanian

50 PME 35-36.

51 Selections: Hackl, Jacobs, and Weber 2010, vol. 2; for Greek and Roman views of the Parthians and their institutions and customs, see, e.g., the contributions in Wiesehöfer 1998; Wiesehöfer and Müller 2017; for economically relevant information, Hackl 2010.

52 Doctrina Addae: Zehnder 2010a (selections with German translation); Song of the Pearl: Zehnder 2010b (selections with German translation). 
Empire, which itself, in Late Antiquity, denied the Arsakids their role in world history. ${ }^{53}$

Third, in contrast to the Achaemenid and Sasanian Empires, there is until today a lack of decidedly economic-historical analyses of the Arsakid Empire, even though it has to be admitted that the task will encounter severe problems of research.

Fourth, economically relevant information is chronologically and spatially unequally distributed. Some data are transferable across time and space, but others are not, or only partly so.

Fifth, most of the information relates to a) trade, especially long-distance trade, and goods traded (Chinese historiography; Periplus; Christian-Jewish literature; Palmyrene inscriptions); b) urbanism and demography (Chinese historiography; Susa surveys et al.; Isidoros); c) agricultural (Nisa ostraca and archaeology; Babylonian texts) and craft production (Greek and Latin authors; Nisa archaeology); d) water management (Nisa ostraca; Susiane surveys; Astronomical Diaries; Isidoros); e) prices and wages (Babylonian texts); f) taxes and duties (Dura parchments; Palmyrene inscriptions; Greek and Latin authors; Jewish texts); and g) general economic conditions (Chinese historiography; Babylonian texts; Greek and Latin authors; coins).

\section{References}

Back, M. 1978. Die sassanidischen Staatsinschriften: Studien zur Orthographie und Phonologie des Mittelpersischen der Inschriften zusammen mit einem etymologischen Index des mittelpersischen Wortgutes und einem Textcorpus der behandelten Inschriften. Leiden and Tehran: Brill and Bibliothèque Pahlavi.

Böck, B. 2010. "Schriftquellen mit Übersetzung und Kommentar: Keilschriftliche Texte: Astronomische Tagebücher." In Hackl, Jacobs, and Weber (2010), vol. 3, 45-127.

Brosius, M. 2006. The Persians: An introduction. London: Routledge.

Canepa, M. P. 2018. The Iranian expanse: Transforming royal identity through architecture, landscape, and the built environment, 550 BCE-642 CE. Berkeley, CA: University of California Press.

Casson, L. 1989. The Periplus Maris Erythraei: Text with introduction, translation, and commentary. Princeton, NJ: Princeton University Press.

Cotton, H. M., W. E. H. Cockle, and F. Millar. 1995. "The papyrology of the Roman Near East: A survey." Journal of Roman Studies 85, 214-235.

Curtis, J., and S. J. Simpson, eds. 2010. The world of Achaemenid Persia: History, art and society in Iran and the ancient Near East. London: I. B. Tauris.

Curtis, V. S., and S. Stewart, eds. 2005. Birth of the Persian Empire. London: I. B. Tauris.

-, eds. 2007. The age of the Parthians. London: I. B. Tauris.

-, eds. 2008. The Sasanian era. London: I. B. Tauris.

Dąbrowa, E. 2011. Studia Graeco-Parthica: Political and cultural relations between Greeks and Parthians. Wiesbaden: Harrassowitz.

53 Wiesehöfer 2017b. 
Diakonoff, I. M., and V. A. Livshits. 1976-2001. Corpus Inscriptionum Iranicarum. Part 2, vol. 2. 1, Parthian Economic Documents from Nisa. 6 vols. London: School of Oriental and Asian Studies.

Dignas, B., and E. Winter. 2007. Rome and Persia in Late Antiquity: Neighbours and rivals. Cambridge: Cambridge University Press.

Dodgeon, M. H., and S. N. C. Lieu, eds. 1991. The Roman eastern frontier and the Persian Wars, $A D$ 226-363: A documentary history. London: Routledge.

Emmerick, R. E., and M. Macuch, eds. 2009. The literature of pre-Islamic Iran. London: I. B. Tauris.

Fox, G., S. N. C. Lieu, and N. Ricklefs. 2005. "Select Palmyrene inscriptions." In I. Gardiner, S. N. C. Lieu, and K. Parry (eds.), From Palmyra to Zayton: Epigraphy and iconography, 27-126. Turnhout: Brepols.

Golze, U., and K. Storm. 2010. "Schriftquellen mit Übersetzung und Kommentar: Chinesische Texte." In Hackl, Jacobs, and Weber (2010), vol. 3, 482-511.

Grajetzki, W. 2011. Greeks and Parthians in Mesopotamia and beyond, 331 BC-AD 224. London: Bloomsbury.

Greatrex, G., and S. N. C. Lieu, eds. 2002. The Roman eastern frontier and the Persian Wars. Part 2, AD 363-630: A narrative sourcebook. London: Routledge.

Gregoratti, L. 2010. “The Palmyrenes and the Arsacid policy.” Вопросы эпиграфики: Сборник статей 4, 21-37.

Gyselen, R., ed. 2009. Sources pour l'histoire et la géographie du monde iranien (224-710). Leuven: Peeters.

-, ed. 2010. Sources for the history of Sasanian and post-Sasanian Iran. Leuven: Peeters.

Hackl, J. 2016. "New additions to the Rahimesu archive: Parthian texts from the British Museum and the World Museum Liverpool." In K. Kleber and R. Pirngruber (eds.), Silver, money and credit: A tribute to Robartus J. van der Spek on the occasion of his 65th birthday on 18th September 2014, 87-106. Leiden: Nederlands Instituut voor het Nabije Oosten.

Hackl, U. 2010. “Das Partherreich im Spiegel der Schriftquellen: Die inneren Verhältnisse im Partherreich: Handel und Wirtschaft." In Hackl, Jacobs, and Weber (2010), vol. 1, 111-124.

Hackl, U., B. Jacobs, and D. Weber, eds. 2010. Quellen zur Geschichte des Partherreiches: Textsammlung mit Übersetzungen und Kommentaren. 3 vols. Göttingen: Vandenhoeck \& Ruprecht.

Hartmann, U. 2011. "Review of U. Hackl, B. Jacobs, and D. Weber, Quellen zur Geschichte des Partherreiches: Textsammlung mit Übersetzungen und Kommentaren.” Humanities - Sozialund Kulturgeschichte 14.03. 2011, www.hsozkult.de/publicationreview/id/rezbuecher-14169.

-. 2017. "Die parthischen Stationen des Isidor von Charax: Eine Handelsroute, eine Militärkarte oder ein Werk geographischer Gelehrsamkeit?” In Wiesehöfer and Müller (2017), 87-125.

-. 2018. "Wege durch Parthien - Straßen, Handelsrouten und Kommunikation im Arsakidenreich." In B. Woytek (ed.), Infrastructure and distribution in ancient economies, 445-472. Wien: Österreichische Akademie der Wissenschaften.

Haruta, S. 2001. "A new translation of the Avroman parchment no. 3 (British Library Or. 8115).” Oriento 44, 125-134.

Hauser, S. R. 2005. “Die ewigen Nomaden? Bemerkungen zu Herkunft, Militär, Staatsaufbau und nomadischen Traditionen der Arsakiden.” In B. Meißner, O. Schmitt, and M. Sommer (eds.), Krieg, Gesellschaft, Institutionen: Beiträge zu einer vergleichenden Kriegsgeschichte, 163208. Berlin: Akademie-Verlag.

-. 2012. “The Arsacid (Parthian) Empire.” In D. T. Potts (ed.), A companion to the archaeology of the ancient Near East, 1001-1020. Malden, MA: Wiley-Blackwell.

-. 2013. "The Arsacids (Parthians)." In D. T. Potts (ed.), The Oxford handbook of ancient Iran, 728-750. Oxford: Oxford University Press. 
-. 2017. "Isidor von Charax $\Sigma \tau \alpha \theta \mu$ oì П $\alpha \rho \theta$ ıкоí - Annäherungen an den Autor, den Routenverlauf und die Bedeutung des Werkes." In Wiesehöfer and Müller (2017), 127-187.

Henkelman, W. F. M., and C. Redard, eds. 2017. Persian religion in the Achaemenid period / La religion perse à l'époque achéménide. Wiesbaden: Harrassowitz.

Hoo, M. 2018. "Ai Khanum in the face of Eurasian globalisation: A translocal approach to a contested site in Hellenistic Bactria." Ancient West and East 17, 161-186.

-. Forthcoming. Eurasian localisms: Towards a translocal approach to Hellenism and inbetweenness in central Eurasia, c. 300 BCE-1 CE. Stuttgart: Franz Steiner.

Hunger, H., ed. 1988-1996. Astronomical diaries and related texts from Babylonia. Vols. 1-3. Vienna: Österreichische Akademie der Wissenschaften.

-, ed. 2001. Astronomical diaries and related texts from Babylonia. Vol. 5, Lunar and planetary texts. Vienna: Österreichische Akademie der Wissenschaften.

-, ed. 2006. Astronomical diaries and related texts from Babylonia. Vol. 6, Goal year texts. Vienna: Österreichische Akademie der Wissenschaften.

-, ed. 2014. Astronomical diaries and related texts from Babylonia. Vol. 7, Almanacs and normal star almanacs. Vienna: Österreichische Akademie der Wissenschaften.

Huyse, P. 1999. Corpus Inscriptionum Iranicarum. Part 3, vol. 1, texts 1, Die dreisprachige Inschrift Šābuhrs I. an der Ka'ba-i Zardušt (ŠKZ). 2 vols. London: School of Oriental and African Studies.

-. 2005. La Perse antique. Paris: Les Belles Lettres.

-. 2008. "Late Sasanian society between orality and literacy." In Curtis and Stewart (2008), 140155.

Jacobs, B. ed. 2014. Parthische Kunst - Kunst im Partherreich. Düsseldorf: Wellem.

Jacobs, B., and R. Rollinger, eds. 2010. Der Achämenidenhof / The Achaemenid Court. Wiesbaden: Harrassowitz.

Jacobs, B., W. F. M. Henkelman, and M. W. Stolper, eds. 2017. Die Verwaltung im Achämenidenreich: Imperiale Muster und Strukturen / Administration in the Achaemenid Empire: Tracing the imperial signature. Wiesbaden: Harrassowitz.

Kettenhofen, E. 2012. Review of Studia Graeco-Parthica: Political and cultural relations between Greeks and Parthians, by E. Dąbrowa. Humanities - Sozial- und Kulturgeschichte 20. 02. 2012, www.hsozkult.de/publicationreview/id/rezbuecher-17304.

Kosmin, P. 2019. Time and its adversaries in the Seleucid Empire. Cambridge, MA: Harvard University Press.

Kuhrt, A. 2007. The Persian Empire: A corpus of sources from the Achaemenid period. 2 vols. London: Routledge.

Lerouge, C. 2007. L'image des Parthes dans le monde gréco-romain: Du début du ler siècle av. J.-C. jusqu'à la fin du Haut-Empire romain. Stuttgart: Franz Steiner.

Leslie, D. D., and K. H. J. Gardiner. 1996. The Roman Empire in Chinese sources. Rome: Bardi.

Lippolis, C., and N. Manassero. 2015. "Storehouses and storage practices in Old Nisa (Turkmenistan)." Electrum 22, 115-142.

Livshits, V. A. 2006. "Three new ostraca documents from Old Nisa." In M. Compareti, P. Raffetta, and G. Scaria (eds.), Ėrān ud Anērān: Studies presented to Boris Il'ic Maršak on the occasion of his 70th birthday, 403-406. Venice: Cafoscarina.

-. 2010. "The Avroman parchment III in Parthian." Anabasis 1, 159-174.

Livshits, V. A., and V. N. Pilipko. 2004. "Parthian ostraca from the central building complex of Old Nisa." Ancient Civilizations from Scythia to Siberia 10, 139-181.

Luther, A. 2015. "Das Königreich Adiabene zwischen Parthern und Römern.” In E. Baltrusch and J. Wilker (eds.), Amici - socii - clientes? Abhängige Herrschaft im Imperium Romanum, 275300. Berlin: Edition Topoi.

-. 2018. "Zu den Dokumenten aus Avroman." Gymnasium 125, 155-177. 
Manning, J. G. 2010. The last Pharaohs: Egypt under the Ptolemies, 305-30 BC. Princeton, NJ: Princeton University Press.

Marciak, M. 2014. Izates, Helena, and Monobazos of Adiabene: A study on literary traditions and history. Wiesbaden: Harrassowitz.

-. 2017. Sophene, Gordyene, and Adiabene: Three regna minora of northern Mesopotamia between East and West. Leiden: Brill.

Millar, F. 1998a. "Dura-Europos under Parthian rule.” In Wiesehöfer (1998), 473-492.

-. 1998b. "Caravan cities: The Roman Near East and long distance trade by land." In M. M. Austin, J. Harries, and C. J. Smith (eds.), Modus operandi: Essays in honour of Geoffrey Rickman, 119-137. London: Institute of Classical Studies.

Minns, E. H. 1915. "Parchments of the Parthian period from Avroman in Kurdistan." Journal of Hellenic Studies 35, 22-65.

Morano, E. 1996. "Two new ostraka from Nisa." In Convegno internazionale sul tema: La Persia e l'Asia Centrale da Alessandro al X secolo: In collaborazione con l'Istituto italiano per il Medio ed Estremo Oriente, 139-145. Rome: Academia Nazionale dei Lincei.

-. 2008. "Iscrizioni partiche da Nisa Vecchia su ostraka e intonaco." In A. Invernizzi and C. Lippolis (eds.), Nisa Partica: Ricerche nel complesso monumentale arsacide 1990-2006, 344-350. Florence: Le Lettere.

-. 2013. "On some recently found ostraca from Old Nisa." In S. Tokhtasev and P. Luria (eds.), Commentationes Iranicae: Vladimiro f. Aaron Livschits nonagenario donum natalicium, 111117. St. Petersburg: Nestor-Historia.

Nippel, W. 2013. "Der Diskurs über die orientalische Despotie im 18. und 19. Jahrhundert: Von Montesquieu zu Marx." In N. Zenzen, T. Hölscher, and K. Trampedach (eds.), Aneignung und Abgrenzung: Wechselnde Perspektiven auf die Antithese von 'Ost' und 'West' in der griechischen Antike, 465-484. Heidelberg: Verlag Antike.

Olbrycht, M. J. 2014. "Parthians, Greek culture and beyond." In K. Twardowska, M. Salamon, S. Sprawski, M. Stachura, and S. Turlej (eds.), Within the circle of ancient ideas and virtues: Studies in honour of Professor Maria Dzielska, 129-141. Cracow: Historia Iagellonica.

-. 2017. "Greeks in the Arsacid Empire." In Wiesehöfer and Müller (2017), 3-27.

Posch, W. 1998. “Chinesische Quellen zu den Parthern.” In Wiesehöfer (1997), 355-364.

Potts, D. T. 2016. The archaeology of Elam: Formation and transformation of an ancient Iranian state. 2nd ed. Cambridge: Cambridge University Press.

Rezakhani, K. 2010. "The road that never was: The Silk Road and trans-Eurasian exchange." Comparative Studies in South Asia, Africa and the Middle East 30.3, 420-433.

Rougemont, G. 2012. Corpus Inscriptionum Iranicarum. Part 2, vol. 1.1, Inscriptions grecques d'Iran et d'Asie centrale. London: School of Oriental and African Studies.

Ruffing, K. 2017. "Der Periplus Maris Erythraei und die Ethnographie der Erythra Thalassa." In R. Rollinger (ed.), Die Sicht auf die Welt zwischen Ost und West (750 v. Chr. -550 n. Chr.) / Looking at the world from the East and the West (750 BCE-550 CE), 185-196. Wiesbaden: Harrassowitz.

Sancisi-Weerdenburg, H. et al. 1987-2010, eds. Achaemenid History. 15 vols. Leiden: Nederlands Instituut voor het Nabije Oosten.

Schippmann, K. 1980. Grundzüge der parthischen Geschichte. Darmstadt: Wissenschaftliche Buchgesellschaft.

Schmitt, R. 1998. "Parthische Sprach- und Namenüberlieferung aus arsakidischer Zeit.” In Wiesehöfer (1997), 163-204.

-. 2000. Corpus Inscriptionum Iranicarum. Part 1, vol. 1, texts 2, The Old Persian inscriptions of Naqsh-i Rustam and Persepolis. London: School of Oriental and African Studies.

-. 2009. Die altpersischen Inschriften der Achaimeniden. Wiesbaden: Reichert. 
-. 2016. Iranisches Personennamenbuch. Vol. 2, Mitteliranische Namen. Fascicle 5, Personennamen in parthischen epigraphischen Quellen. Vienna: Österreichische Akademie der Wissenschaften.

-. 2017. "Isidors Stathmoi Parthikoi aus Sicht der iranischen Toponomastik." In Wiesehöfer and Müller (2017), 189-220.

Schuol, M. 2000. Die Charakene: Ein mesopotamisches Königreich in hellenistisch-parthischer Zeit. Stuttgart: Franz Steiner.

-. 2017. "Isidor von Charax und die literarische Gattung der stathmoi." In Wiesehöfer and Müller (2017), 71-85.

Shayegan, M. R. 2011. Arsacids and Sasanians: Political ideology in post-Hellenistic and Late Antique Persia. Cambridge: Cambridge University Press.

Sinisi, F. 2012. "The coinage of the Parthians." In W. E. Metcalf (ed.), The Oxford handbook of Greek and Roman coinage, 275-294. Oxford: Oxford University Press.

-. 2014. "Sources for the history of art of the Parthian period: Arsacid coinage as evidence for continuity of imperial art in Iran." Parthica 16, 9-59.

Speidel, M. A. 2016. "Augustus-Tempel in Indien und im Partherreich? Zur Tabula Peutingeriana und zum römischen Kaiserkult ausserhalb des Römischen Reiches." In A. Kolb and M. Vitale (eds.), Kaiserkult in den Provinzen des Römischen Reiches: Organisation, Kommunikation und Repräsentation, 101-121. Berlin: De Gruyter.

Thommen, L. 2010a. "Schriftquellen mit Übersetzung und Kommentar: Griechische und lateinische Texte: Inschriften, Pergamente und Papyri: Iran: Griechisches Pergament von Avroman, Nr. I-II." In Hackl, Jacobs, and Weber (2010), vol. 2, 467-476.

-. 2010b. "Griechische und lateinische Texte: Inschriften, Pergamente und Papyri: Syrien: Dura Europos: Griechisches Pergament aus Dura Europos: P. Dura 18 und 20." In Hackl, Jacobs, and Weber (2010), vol. 2, 445-452.

-. 2010c. "Schriftquellen mit Übersetzung und Kommentar: Griechische und lateinische Texte: Literarische Texte: Periplus Maris Erythraei.” In Hackl, Jacobs, and Weber (2010), vol. 2, 300-302.

Van der Spek, R. J. 1997-1998. "New evidence from the Babylonian astronomical diaries concerning Seleucid and Arsacid history." Archiv für Orientforschung 44/45, 167-175.

-. 1998. "Cuneiform documents on Parthian history: The Rahimesu archive: Materials or the study of the standard of living." In Wiesehöfer (1998), 205-258. Stuttgart: Franz Steiner.

Weber, D. 2010a. "Schriftquellen mit Übersetzung und Kommentar: Parthische Texte: Avrōmān III (Tafel VII)." In Hackl, Jacobs, and Weber (2010), vol. 2, 566-567.

-. 2010b. "Schriftquellen mit Übersetzung und Kommentar: Parthische Texte: Nisa-Dokumente." In Hackl, Jacobs, and Weber (2010), vol. 2, 494-561.

Welles, C., R. O. Fink, and J. F. Gilliam. 1959. The excavations at Dura-Europos: Final report. Vol. 5.1, The parchments and papyri. New Haven, CT: Yale University Press.

Wenke, R. J. 1975-1976. "Imperial investments and agricultural developments in Parthian and Sasanian Khuzistan, 150 BC-AD 640." Mesopotamia 10/11, 31-221.

Wiesehöfer, J. ed. 1998. Das Partherreich und seine Zeugnisse / The Arsacid Empire: Sources and documentation. Stuttgart: Franz Steiner.

-. 1999. "Kyros, der Schah und 2500 Jahre Menschenrechte: Historische Mythenbildung zur Zeit der Pahlavi-Dynastie." In S. Conermann (ed.), Mythen, Geschichte(n), Identitäten: Der Kampf um die Vergangenheit, 55-68. Hamburg: E.B.-Verlag.

-. 2000. “'Denn Orodes war der griechischen Sprache und Literatur nicht unkundig...': Parther, Griechen und griechische Kultur." In R. Dittmann, U. Löw, P. Matthiae, R. Mayer-Opificius, and S. Thürwächter (eds.), Variatio delectat: Iran und der Westen: Gedenkschrift für P. Calmeyer, 703-721. Münster: Ugarit.

-. 2004a. Ancient Persia from 550 BC to 650 AD. 3rd ed. London: I. B. Tauris. 
-. 2004b. "Vermittler zwischen Ost und West: Die Parther." In T. Stöllner, R. Slotta, and

A. Vatandoust (eds.), Persiens antike Pracht: Bergbau, Handwerk, Archäologie, 2, 408-415.

Bochum: Deutsches Bergbau-Museum.

-. 2005. Iraniens, Grecs et Romains. Paris: Association pour l'Avancement des Études Iraniennes.

-. 2006. "Statt einer Einleitung: 'Randkultur' oder 'Nabel der Welt'? Das Sasanidenreich und der

Westen: Anmerkungen eines Althistorikers." In Wiesehöfer and Huyse (2006), 9-28.

-. 2007. "Alte Geschichte und Alter Orient, oder: Ein Plädoyer für Universalgeschichte." In

R. Rollinger, A. Luther, and J. Wiesehöfer (eds.), Getrennte Wege? Kommunikation, Raum

und Wahrnehmung in der Alten Welt, 595-616. Heidelberg: Verlag Antike.

-. 2014. "Parther und Sasaniden: Imperien zwischen Rom und China." In M. Gehler and R.

Rollinger (eds.), Imperien und Reiche in der Weltgeschichte: Epochenübergreifende und globalhistorische Vergleiche. Vol. 1, 449-478. Wiesbaden: Harrassowitz.

-. 2015a. Das frühe Persien: Geschichte eines antiken Weltreichs. 5th ed. Munich: C. H. Beck.

-. 2015b. "Greek poleis in the Near East and their Parthian overlords." In A. M. Kemezis (ed.), Urban dreams and realities in antiquity: Remains and representations of the ancient city, 328-346. Leiden: Brill.

-. 2016. "Greeks, Iranians and Chinese on the Silk Road." In S. N. C. Lieu and G. B. Mikkelsen (eds.), Between Rome and China: History, religions and material culture of the Silk Road, 1-17. Turnhout: Brepols.

-. 2017a. "Alte Geschichte und internationale Geschichte." In B. Heider-Wilson, W. D. Godsey, and W. Mueller (eds.), Internationale Geschichte in Theorie und Praxis: International history in theory and practice, 65-79. Vienna: Österreichische Akademie der Wissenschaften.

-. 2017b. "Ērān ud Anērān: Sasanian patterns of worldview." In R. Strootman and M. J. Versluys (eds.), Persianism in Antiquity, 381-391. Stuttgart: Franz Steiner.

Wiesehöfer, J., and P. Huyse, eds. 2006. Ėrān ud Anērān: Studien zu den Beziehungen zwischen dem Sasanidenreich und der Mittelmeerwelt. Stuttgart: Franz Steiner.

Wiesehöfer, J., and S. Müller, eds. 2017. Parthika: Greek and Roman authors' views of the Arsacid Empire / Griechisch-römische Bilder des Arsakidenreiches. Wiesbaden: Harrassowitz.

Young, G. K. 2001. Rome's eastern trade: International commerce and imperial policy, 31 BC$A D$ 305, London: Routledge.

Zehnder, M. 2010a. "Schriftquellen mit Übersetzung und Kommentar: Aramäische Texte: Literarische Texte: Die Doctrinae Addae." in Hackl, Jacobs, and Weber (2010), vol. 3, 209-218.

-. 2010b. "Schriftquellen mit Übersetzung und Kommentar: Aramäische Texte: Literarische Texte: Thomasakten und Perlenlied." In Hackl, Jacobs, and Weber (2010), vol. 3, 237-261. 


\title{
12 Qin and Han Evidence
}

\author{
Kathrin Leese-Messing \\ 12.A Transmitted Texts
}

\section{Introduction}

Society obviously must have farmers before it can eat, foresters, fishermen, miners, etc., before it can make use of natural resources; craftsmen before it can have manufactured goods; and merchants before they can be distributed. But once these exist, what need is there for government directives, mobilizations of labor, or periodic assemblies? Each man has only to be left to utilize his own abilities and exert his own strength to obtain what he wishes. Thus, when a commodity is very cheap, it invites a rise in price; when it is very expensive, it invites a reduction. When each person works away at his own occupation and delights in his own business, then, like water flowing downward, goods will naturally flow forth ceaselessly day and night without having been summoned, and the people will produce commodities without having been asked.

故待農而食之, 虞而出之, 工而成之, 商而通之。此寧有政教發徵期會哉? 人各任其能, 竭其力, 以得所欲。故物賤之徵貴, 貴之徵賤, 各勸其業, 樂其事, 若水之趨下, 日夜無休時, 不召而自來, 不求而民出之。1

This advice was not written by some eighteenth- or nineteenth-century classical economist. The fact that it might well be is astounding in itself, considering that it was an ancient Chinese historian, Sima Qian 司馬遷 (145 or 135-ca. 87 BCE), who recorded it more than 2,000 years ago. Not quite without reason, this passage has often been described as an ancient precursor of Adam Smith's (1729-1790) 'invisible hand.' It has even been suggested, albeit wrongly, that it was his knowledge of Sima Qian's ideas that inspired Adam Smith in developing this notion. ${ }^{2}$ The question of how far the ancient author's ideas are in fact comparable to modern theories of competitive, self-regulating markets is, to be sure, much more complex than this isolated quotation could possibly suggest. But apart from this particular question, the quotation illustrates very well the high degree of interest and sometimes sophistication that several ancient Chinese works reveal with regard to economic considerations. In early imperial China, economic circumstances as well as policies such as currency reforms, price stabilization schemes, or the introduction of state monopolies, were acknowledged as important factors for a state's well-being, and contem-

1 Shiji 129.3254, trans. Watson 1993, 434.

2 Young 1996; McCormick 1999; Chiu and Yeh 1999.

Note: I would like to thank Armin Selbitschka for valuable comments on an earlier draft of this chapter.

Ә Open Access. (C) 2020 Kathrin Leese-Messing, published by De Gruyter. (c) BY-NC-ND This work is licensed under the Creative Commons Attribution-NonCommercial-NoDerivatives 4.0 License.

https://doi.org/10.1515/9783110607741-018 